\title{
Remote spatial analysis lacking ethnographic grounding mischaracterizes sustainability of Indigenous burning regime
}

\author{
James R. Welch ${ }^{(\mathbb{D}}$, Eduardo S. Brondizio ${ }^{2}$ \& Carlos E. A. Coimbra Jr. ${ }^{\mathbb{1}}$ \\ ${ }^{1}$ Fundação Oswaldo Cruz, Escola Nacional de Saúde Pública Sergio Arouca, Rio de Janeiro, RJ, Brasil. \\ ${ }^{2}$ Indiana University Bloomington, Department of Anthropology Bloomington, Indiana, United States. \\ *Corresponding author: welch@ensp.fiocruz.br
}

WELCH, J.R., BRONDIZIO, E.S., COIMBRA JR., C.E.A. Remote spatial analysis lacking ethnographic grounding mischaracterizes sustainability of Indigenous burning regime. Biota Neotropica 22(1): e20211220. https://doi.org/10.1590/1676-0611-BN-2021-1220

\begin{abstract}
Scientific research that purports to evaluate Indigenous fire regimes in the absence of ethnographically contextualized ecological data runs the risk of exacerbating the fire blame game and providing evidence to support distorted narratives advanced by anti-Indigenous advocates. Spatial analysis of fire scars in Indigenous territories can be an effective tool for characterizing cultural fire regimes in terms of distribution and frequency, especially when qualified by linkages to different local ecosystems. A recently published article drew on fire scar mapping from satellite imagery to assess anthropogenic fire distribution and frequency in the Pimentel Barbosa Indigenous Land, Central Brazil. The authors use their findings to characterize A'uwẽ (Xavante) use of fire as unmanaged and a model of unsustainable use of cerrado resources. In this article, we discuss Aguiar \& Martins's recent paper in light of our long-term research on A'uwẽ hunting with fire in the Pimentel Barbosa Indigenous Land, arguing that A'uwẽ hunters do burn according to established cultural protocols, manage their use of fire for conservationist purposes, and do not cause environmental degradation by burning. Keywords: Spatial analysis, fire management, fire regimes, Indigenous fire use, cerrado.
\end{abstract}

\section{Análise espacial remota sem embasamento etnográfico descaracteriza a sustentabilidade do regime de queimada indígena}

\begin{abstract}
Resumo: A pesquisa científica que pretende avaliar regimes indígenas de queimadas na ausência de dados ecológicos contextualizados etnograficamente corre o risco de exacerbar o jogo de culpabilização do fogo, fornecendo evidências para apoiar narrativas distorcidas apresentadas por militantes anti-indígenas. A análise espacial de cicatrizes de fogo em territórios indígenas pode ser uma ferramenta eficaz para caracterizar regimes culturais de fogo em termos de distribuição e frequência, especialmente quando qualificada por ligações a diferentes ecossistemas locais. Um artigo publicado recentemente se baseou no mapeamento de cicatrizes de fogo a partir de imagens de satélite para avaliar a distribuição e frequência antropogênica de fogo na Terra Indígena Pimentel Barbosa, Brasil Central. Os autores usam seus resultados para caracterizar o uso do fogo pelos A’uwẽ (Xavante) como não manejado e um modelo insustentável de uso de recursos do cerrado. Neste artigo, discutimos o artigo recente de Aguiar \& Martins à luz de nossa pesquisa de longa duração sobre a caçada com fogo praticada pelos A’uwẽ na Terra Indígena Pimentel Barbosa, argumentando que os caçadores A'uwẽ queimam de acordo com protocolos culturais estabelecidos, manejam o fogo de maneira conservacionista e não causam degradação ambiental pela queimada.

Palavras-chave: Análise espacial, manejo do fogo, regimes de fogo, uso indígena do fogo, cerrado.
\end{abstract}

\section{Introduction}

Indigenous and traditional peoples who ignite landscape vegetation for subsistence purposes are often inappropriately blamed for purported increases in land degradation and carbon emissions even though agribusiness and other forms of non-traditional occupation contribute to these problems many times over in comparison (Fowler \& Welch 2018). Subsistence burning accompanied by traditional cultural knowledge of appropriate fire regimes in fire-prone landscapes is well documented in diverse world contexts to increase biodiversity, promote vegetative regeneration, and reduce wildfire occurrence (Bird et al. 2016, Kelly et al. 2020, Kimmerer \& Lake 2001, Trauernicht et al. 2015, Welch et al. 2018). Scientific research that purports to evaluate Indigenous fire regimes in the absence of ethnographically contextualized ecological data runs the risk of exacerbating the fire blame game and providing evidence to support distorted narratives advanced by anti-Indigenous advocates. As observed by Arruda et al (2018, p. 5), "evidence from the literature has shown that the response of biodiversity to fire is context-dependent."

Spatial analysis of fire scars in Indigenous territories can be an effective tool for characterizing cultural fire regimes in terms of 
distribution and frequency, especially when qualified by linkages to different local ecosystems. Much of this research provides evidence of patchy distribution and varied frequencies according to local ecosystems (Price et al. 2005, Russell-Smith et al. 1997, Vigilante et al. 2004). Studies that benefit from remote sensing analysis of vegetation cover change over time tend to show land cover stability or reforestation under Indigenous management, even when burn frequency in some ecosystems approaches annual (Mistry et al. 2016, Welch et al. 2013a). Indigenous burning influences ecosystem structure and plant diversity profiles, favoring some taxa over others, as has been reported in historical documents and ethnographic studies for decades to centuries, depending on the location (Anderson 2005, Bowman \& Prior 2004, Pascoe 2014).

A recently published article drew on fire scar mapping from satellite imagery to assess anthropogenic fire distribution and frequency in the Pimentel Barbosa Indigenous Land, Central Brazil (Aguiar \& Martins 2020). This particular territory, inhabited by A'uwẽ (Xavante) people, is well known in the literature as a rare contemporary example of an Indigenous society that continues to burn the cerrado landscape during large group hunts according to long established cultural protocols. A'uwẽ hunters aim to simultaneously elevate hunting yields and preserve the non-human landscape (flora and fauna) in such a manner as to ensure its productivity in the long term (Melo \& Saito 2013, 2011, Welch 2015, 2014, Welch et al. 2013a, Welch \& Coimbra Jr. 2019). However, the article by Aguiar \& Martins paints a very different picture, characterizing A'uwẽ burning during hunting events as "indiscriminate fire use" contributing to "a burning regime without clear control of frequency or size" (2020, p. 16). According to the authors, the disjunction and reduction of their territory and integration of their Indigenous culture into the Brazilian national culture caused them to undergo a process of cultural fragmentation and abandonment of their traditional burning models. Thus, the authors argue, the burn pattern became more frequent and transformed into a model of unsustainable resource exploitation.

Our ethnographic and ecological experience accompanying A'uwẽ burning during group hunts over the last 17 years suggests that these characterizations are not only ethnographically incomplete, considering that the authors did no field work, but are also dangerous distortions of fact that contribute to a biased and unsubstantiated characterization of an Indigenous people as wanton ecological destroyers. Considering the larger regional frame of expansive non-Indigenous agribusiness vegetation clearing for cattle pasture and monoculture crops, the authors' characterization of A'uwẽ burning as unsustainable is based on speculation, ignores the Pimentel Barbosa Indigenous Land's important role as a green island amid veritable ecological desert, and appears to unfairly single out the A'uwẽ due to their cultural identity. In this article, we discuss Aguiar \& Martins's arguments in light of our long-term research on A'uwẽ hunting with fire in the Pimentel Barbosa Indigenous Land, arguing that A'uwẽ hunters do burn according to established cultural protocols, manage their use of fire for conservationist purposes, and do not cause environmental degradation by burning.

\section{Mapping of Indigenous fire regime with boots off the ground}

The core methodology of the Aguiar \& Martins (2020) study was to measure the distribution (area) and frequency (repetition in the same locations) of anthropogenic fires within the Pimentel Barbosa
Indigenous Land during the dry season months of May through October from 1984 to 2018 . A total of 153 satellite images were used to measure fire scars using polygons generated with the GIMP tool Fuzzy Select. Polygons created from multiple images for the same year were joined to create annual binary images distinguishing burned and unburned areas. These images were combined to create a composite image showing overall burn frequencies within the boundaries of the Indigenous land. The colors chosen for illustrating the frequency scale ranges from a warm yellow signifying fire in just one out of 34 years to a menacing black for fire in all 34 years. In between these extremes, fire in just five of 34 years was represented by a flame-like shade of orange. These color choices conspire to produce a burn frequency map that looks well charred even in areas that were burned during less than half of the evaluated years, which corresponds with the authors' own recommendation of burning no more frequently than every two years in savanna vegetation types.

Burn frequencies were also calculated according to six categories: five types of vegetation and one land use type (agriculture). These vegetation/land use frequencies were classified by the number of years out of the total of 34 that showed burn scars: Low Frequency (burns registered in 1 to 8 years), Medium Frequency (in 9 to 16 years), and High Frequency (in 17 to 34 years). No justification for these cutoff points was provided.

The authors characterized the resulting scar pattern as "an intense fire regime" (Aguiar \& Martins, 2020, p. 7) based on the observation that fire was detected somewhere within the Indigenous land in all years. The burning regime was also somewhat mysteriously described in terms of the total area burned in all 34 years in hectares, presented as a percentage of the area of the Indigenous land (1.534,39\%). The relevance and comparability of this awkward measure for evaluating fire regime intensity is unclear.

According to the authors, these yardsticks provide evidence of supposedly excessive burning that should be considered harmful to the landscape. However, they are measures without meaning based on arbitrary cutoff points, inconsistent criteria, and nonsensical calculations. We argue that the measures used by Aguiar \& Martins serve more to obscure than to clarify the nature of the A'uwẽ anthropogenic fire regime in the Pimentel Barbosa Indigenous Land.

Several methodological and interpretive problems deriving from the study's lack of ethnographic data are apparent. For example, the vegetation/land use base map used was produced for an unpublished environmental impact report (Azanha 2013) contracted by a governmental railroad corporation, for the purpose of authorizing a cargo railway planned to cross the A'uwẽ region, intended for internal circulation and not subject to peer review. Consequently, Aguiar \& Martins repeated Azanha's error of labeling areas as under active agricultural use when they are in fact former cattle pastures from the 1970s, when ranches occupied lands that were subsequently included within the borders of the Pimentel Barbosa Indigenous Land and are now under Indigenous management. At the time of their use, these areas were planted with fodder plants, generally introduced African grasses (e.g., Hyparrhenia rufa (Nees) Stapf, Melinis minutiflora P. Beauv., Andropogon gayanus Kunth, Megathyrsus maximus (Jacq.) B. K. Simon \& S. W. L. Jacobs, and Urochloa spp.). These invasive taxa continue to dominate in the areas they were once planted and contribute to wildfires due to their higher fuel potential and burning temperatures (Hoffmann et 
al. 2004, Pivello et al. 1999, Rossi et al. 2014). This ecological history is necessary for interpreting the finding that $99,08 \%$ of "agricultural" areas was burned during the study period.

Another example is evident in the discussion of results, in which the authors cite sparse literature to assert that traditional burning models have been abandoned and current use of fire is irrational and repetitive (Aguiar \& Martins 2020). However, the sources cited (Fragoso et al. 2000, Leeuwenberg 1994) do not argue for or present evidence in support of such extreme positions. It would seem the authors introduced bias in their characterizations of these references in order to sustain the characterization that culturally informed and managed burning is a thing of the past, having been replaced by uncontrolled pyromania unanchored from tradition.

The authors then delve into the speculative endeavor of guessing what undesirable environmental impacts this supposed uncontrolled burning is having. For example, they postulate that "indiscriminate" (Aguiar \& Martins 2020, p. 14) burning may reduce biodiversity and affect climatic processes. They also construct the argument that native grasslands are particularly flammable, which could lead to a feedback loop whereby fire reduces tree cover, favoring the expansion of grasses, thereby increasing the flammability of the land cover, and ultimately encouraging the occurrence of new fires. Additionally, they argue that A'uwẽ burning could reduce plant biomass and litter, altering the ecosystemic flows of energy, nutrients, and water. These proposed outcomes are unverified for the Pimentel Barbosa Indigenous Land and depend on the mistaken ethnographic presumption that A'uwẽ hunters are reckless and unstoppable igniters of the tropical savanna vegetation.

\section{Ethnographic context of managed burning at Pimentel Barbosa}

A'uwẽ hunters are deliberative people. Whether or not fire is to be used, group hunts are planned, discussed, and debated for hours, days, months, and even years before they occur (Welch 2014). In the past, before the population was settled within the boundaries of a relatively small Indigenous land, which occurred in the 1970s (Welch et al. 2013b), they deliberated extensively about where and when to hunt for what purposes. Among their considerations were where desired large game animals were believed to be abundant, when they would be fat from eating seasonally available foods, and when ceremonial occasions involving gifts of game meat would be held. Such ceremonial events included weddings and rites of passage into adulthood. According to elders, at that time, they were free to hunt anywhere within an enormous traditional territory and therefore did not need to factor conservation of limited hunting grounds into their discussions. Considering that they often hunted while on trek away from the main village, they could distribute their hunting activities far and wide and thereby not cause over taxation of any particular place.

Now as then, hunting with fire is popular because it is an efficient means of acquiring large quantities of game meat in a short period of time and because it is a festive social occasion that hunters of all ages enjoy. It is also a ritual occasion, with representatives of opposite exogamous moieties competing in a foot race that involves running along opposite semicircular paths towards a predesignated ending point some four to seven kilometers distant (Welch 2014). These runners ignite the landscape vegetation as they go while exerting themselves to arrive first at the finishing point and thereby earn bragging rights. This race produces a temporary ring of fire, within which other hunters walk while igniting vegetation in such a manner as to produce an irregular mosaic of burnt, burning, and unburnt spaces. The fire serves to flush out game (not entrap it within a circular fire), which is dispatched as it runs through open spaces in search of cover.

A'uwẽ hunters are keenly aware of the potential ecological pressures that burning within their limited contemporary Indigenous land might cause. It is for this reason that they first sought to collaborate with ecologist Frans Leeuwenberg in studying the ecological impacts of their hunting practices and consider measures to mitigate against over hunting or excessive use of fire (Leeuwenberg 1997, Leeuwenberg \& Robinson 2000). The results of that study are evident today as A'uwẽ hunters continue to deliberate based on its recommendations that hunting fires be distributed temporally and spatially by rotating hunting grounds and avoiding repetitive burns close to villages. Since that first study, they have collaborated with numerous other ecologists to evaluate the impacts of their hunting practices, none of which documented decreased fauna or loss of land cover as a result of their managed burning practices within the Indigenous land (Briani et al. 2004, Prada 2001, Villalobos 2002, Welch et al. 2013a).

When contemporary hunters deliberate hunting with fire, conservation issues are at the top of their list of considerations thanks in part to increased awareness generated through their collaborations with ecologists. Besides rotating hunting grounds, as recommended by Leeuwenberg, they also consider traditional ecological knowledge about when and how often each specific location should be burned. As elders tell younger hunters, according to traditional ecological knowledge and burning protocols, each location has its own proper fire regime, including when in the yearly cycle it should be ignited and with what frequency it should be burned to allow for regeneration and accumulation of adequate quantities of dead biomass. Some taller vegetation types burned in the late dry season require three to four-year intervals, while open grasslands burned at the beginning of the dry season may require only one or two years. They also consider ambient moisture, weather, wind, and natural fire barriers to help avoid fires getting out of control. A well-managed hunting fire burns fast due to adequate fuel but mostly remains cool and restricted to the understory. Also, a well-managed fire is considered to be one that was planned and executed according to traditional fire ecology knowledge.

These ideals are not always attained, especially as younger and less experienced hunters assume responsibility for planning hunting fires. Occasionally a fire will escape their control and continue burning from one day to the next, sometimes incinerating hunting grounds that had been reserved for future use. This is most common in the late dry season when the vegetation is highly combustible. When this happens, elders call meetings to discuss what went wrong and how to prevent it from occurring again in the future. The solution may involve a combination of insights from traditional ecological knowledge and from contemporary knowledge coconstructed with their ecologist partners. A'uwẽ hunters are responsive to all sources of information available to them and utilize this knowledge for conservation purposes, including burning for the long-term sustainability and productivity of the landscape and its non-human life. Elder and youth hunters express concern about the possibility of burning too frequently, but in our experience premature burning result in unproductive hunts, as there is not enough ground fuel to sustain an effective fire. When this happens, elders educate their younger hunting companions about the importance of 
burning less frequently in that particular location or vegetation type. Burning errors are always discussed at length and remembered into the future so they are not repeated.

The ecological results of these conservation efforts are striking. The Pimentel Barbosa Indigenous Land does not suffer from loss of vegetation cover. Comparing 1973 and 2010, deforestation within the boundaries of the land remained unchanged at $0.6 \%$ (Welch et al. 2013a). During the intervening years, the boundaries were expanded to include former cattle ranches with pastures planted with invasive African grasses. These adjustments resulted in temporarily elevated proportions of deforested area, reaching $1.9 \%$ in 2000 , which declined again after these lands previously degraded by agribusiness were returned to Indigenous management with fire. Our analysis of burning patterns from 2007 to 2010 revealed that vegetation maintenance or recuperation occurred even in areas of high fire periodicity, including locations that burned in three or more consecutive years.

\section{Conclusion: Dangers of misleading scientific publications}

There is a danger in exaggerating or mischaracterizing the ethnographic context of anthropogenic burning by Indigenous peoples and smallholders. They may be blamed for problems that do not exist or are overwhelmingly caused by others. In the case of the A'uwẽ of the Pimentel Barbosa Indigenous Land, they have long been blamed for causing deforestation by burning while hunting in groups in the absence of any supporting data whatsoever and in denial of the real source of environmental degradation in the cerrado, which is agribusiness (Welch et al. 2013a). It is incumbent upon scientists to avoid playing into these biased blame games and refrain from repeating unsubstantiated rumors. Abundant scientific research has shown that contemporary A'uwẽ anthropogenic fire regimes within the Pimentel Barbosa Indigenous Land has not caused game animal depopulation since Leeuwenberg warned of over hunting based on data collected in 1991 and 1992 (Leeuwenberg 1997, Leeuwenberg \& Robinson 2000) and has not caused deforestation since 1973 (Welch et al. 2013a).

By misconstruing the A'uwẽ as reckless burners unhinged from tradition, Aguiar \& Martins (2020) risk providing the anti-Indigenous cause with apparent evidence that Indigenous peoples are irresponsible caretakers of their lands and therefore undeserving of them. This is no small thing considering that the current presidential administration in Brazil has expressed interest in reducing Indigenous lands in number and size. Nonscientific methods including the use of obscuring measures of burning frequency and intensity and ethnographic mischaracterization can only serve to punish a minority subsistence-based population for ecological crimes it has not committed.

\section{Associate Editor}

Carlos Joly

\section{Author Contributions}

James R. Welch: Conceptualization, Investigation, Writing Original draft preparation, Writing - Review \& editing.
Eduardo S. Brondizio: Conceptualization, Investigation, Writing Original draft preparation, Writing - Review \& editing.

Carlos E. A. Coimbra Jr.: Conceptualization, Investigation, Writing - Original draft preparation, Writing - Review \& editing.

\section{Conflicts of interest}

None declared.

\section{Ethics}

No permissions required.

\section{References}

AGUIAR, L.L. \& MARTINS, P.T.A. 2020. Regime de queima na Terra Indígena Pimentel Barbosa, MT, Brasil. Mercator 19:e19018.

ARRUDA, F.V., SOUSA, D.G., TERESA, F.B., PRADO, V.H.M., CUNHA, H.F., IZZO, T.J. 2018. Trends and gaps of the scientific literature about the effects of fire on Brazilian Cerrado. Biota Neotrop 18:e20170426.

ANDERSON, M.K. 2005. Tending the wild: Native American knowledge and the management of California's Natural Resources. University of California Press, Berkeley.

AZANHA, G. 2013. Estudos etnoecológicos dos impactos nas TIs ParabubuCuluene, Areões, Pimentel Barbosa e Marechal Rondon: Povo Xavante (componente indígena do processo de licenciamento da EF 354 - Xavante). STE/VALEC, Brasília.

BIRD, D.W., BLIEGE BIRD, R., CODDING, B.F. \& TAYLOR, N. 2016. A landscape architecture of fire: cultural emergence and ecological pyrodiversity in Australia's Western Desert. Curr Anthropol 57:S65-S79.

BOWMAN, D.M. \& PRIOR, L.D. 2004. Impact of Aboriginal landscape burning on woody vegetation in Eucalyptus tetrodonta savanna in Arnhem Land, northern Australia. J Biogeogr 31:807-817.

BRIANI, D.C., PALMA, A.R., VIEIRA, E.M. \& HENRIQUES, R.P. 2004. Post-fire succession of small mammals in the Cerrado of Central Brazil. Biodivers Conserv 13:1023-1037.

FOWLER, C.T. \& WELCH, J.R., 2018. Lifeways enhancing fire ecology: An introduction. In Fire otherwise: ethnobiology of burning for a changing world (C.T. Fowler \& J.R. Welch, eds). The University of Utah Press, Salt Lake City, p.1-21.

FRAGOSO, J.M.V., SILVIUS, K.M. \& VILLALOBOS, M.P. 2000. Manejo de fauna na reserva Xavante Rio das Mortes: cultura indigena e método cientifico integrados para conservação. World Wildlife Fund Brazil, Brasília.

HOFFMANN, W.A., LUCATELLI, V.M.P., SILVA, F.J., AZEUEDO, I.N., MARINHO, M.S., ALBUQUERQUE, A.M.S., LOPES, A.O. \& MOREIRA, S.P. 2004. Impact of the invasive alien grass Melinis minutiflora at the savanna-forest ecotone in the Brazilian Cerrado. Divers Distrib 10:99-103.

KELLY, L.T., GILJOHANN, K.M., DUANE, A., AQUILUÉ, N., ARCHIBALD, S., BATLLORI, E., BENNETT, A.F., BUCKLAND, S.T., CANELLES, Q., CLARKE, M.F., FORTIN, M.-J., HERMOSO, V., HERRANDO, S., KEANE, R.E., LAKE, F.K., MCCARTHY, M.A., MORÁN-ORDÓÑEZ, A., PARR, C.L., PAUSAS, J.G., PENMAN, T.D., REGOS, A., RUMPFF, L., SANTOS, J.L., SMITH, A.L., SYPHARD, A.D., TINGLEY, M.W. \& BROTONS, L. 2020. Fire and biodiversity in the Anthropocene. Science 370:eabb0355.

KIMMERER, R.W. \& LAKE, F.K. 2001. Maintaining the mosaic: the role of indigenous burning in land management. J For 99: 36-41.

LEEUWENBERG, F.J., 1997. Manejo de fauna cinegética na reserva indígena Xavante de Pimentel Barbosa, Estado de Mato Grosso. In Manejo e conservação de vida silvestre no Brasil (C. Valladares-Padua \& R.E. Bodmer, eds.). MCT-CNPq/Sociedade Civil Mamirauá, Brasília, p.233-238. 
LEEUWENBERG, F.J., 1994. Análise etno-zoológica e manejo da fauna cinegética na Reserva Indígena Xavante Rio das Mortes, aldeia Tenitipa, Mato Grosso, Brasil. Centro de Pesquisa Indígena - CPI, Wildlife Conservation International - WCI, Fundo Mundial para a Natureza - WWF, Gaia Foundation, s.l.

LEEUWENBERG, F.J. \& ROBINSON, J.G. 2000. Traditional management of hunting by a Xavante community in Central Brazil: The search for sustainability. In Hunting for Sustainability in Tropical Forests (J.G. Robinson \& E.L. Bennett, eds). Columbia University Press, New York, p.375-394.

MELO, M.M. \& SAITO, C.H. 2013. The practice of burning savannas for hunting by the Xavante Indians based on the stars and constellations. Soc Nat Resour 26: 478-

MELO, M.M. \& SAITO, C.H. 2011. Regime de queima das caçadas com uso do fogo realizadas pelos Xavante no cerrado. Biodiversidade Brasileira 1:97-109.

MISTRY, J., BILBAO, B.A. \& BERARDI, A. 2016. Community owned solutions for fire management in tropical ecosystems: case studies from Indigenous communities of South America. Philos Trans R Soc Lond B Biol Sci 371: 20150174.

PASCOE, B. 2014. Dark emu: black seeds agriculture or accident? Magabala Books, Broome, W.A.

PIVELLO, V.R., SHIDA, C.N. \& MEIRELLES, S.T. 1999. Alien grasses in Brazilian savannas: a threat to biodiversity. Biodivers Conserv 8:1281-1294.

PRADA, M. 2001. Effects of fire on the abundance of large mammalian herbivores in Mato Grosso, Brazil. Mammalia 6: 55-61.

PRICE, O., EDWARDS, A., CONNORS, G., WOINARSKI, J., RYAN, G., TURNER, A. \& RUSSELL-SMITH, J. 2005. Fire heterogeneity in Kakadu National Park, 1980-2000. Wildl. Res. 32:425-433.

ROSSI, R.D., MARTINS, C.R., VIANA, P.L., RODRIGUES, E.L. \& FIGUEIRA, J.E. 2014. Impact of invasion by molasses grass (Melinis minutiflora P. Beauv.) on native species and on fires in areas of campocerrado in Brazil. Acta Bot Bras 28: 631-637.

RUSSELL-SMITH, J., RYAN, P.G. \& DURIEU, R. 1997. A LANDSAT MSSDerived fire history of Kakadu National Park, Monsoonal Northern Australial, 1980-94: seasonal extent, frequency and patchiness. J Appl Ecol 34:748-766.
TRAUERNICHT, C., BROOK, B.W., MURPHY, B.P., WILLIAMSON, G.J. \& BOWMAN, D.M. 2015. Local and global pyrogeographic evidence that indigenous fire management creates pyrodiversity. Ecol Evol 5:1908-1918.

VIGILANTE, T., BOWMAN, D.M.J., FISHER, R., RUSSELL-SMITH, J. \& YATES, C. 2004. Contemporary landscape burning patterns in the far North Kimberley region of north-west Australia: human influences and environmental determinants. J Biogeogr 31:1317-1333.

VILLALOBOS, M.P. 2002. Efeito de fogo e da caça na abundância de mamíferos na Reserva Xavante do Rio das Mortes, MT, Brasil (Doctoral dissertation). Universidade de Brasília, Brasília.

WELCH, J.R. 2015. Learning to hunt by tending the fire: Xavante youth, ethnoecology, and ceremony in Central Brazil. J Ethnobiol 35:183-208.

WELCH, J.R. 2014. Xavante ritual hunting: anthropogenic fire, reciprocity, and collective landscape management in the Brazilian Cerrado. Hum Ecol 42:47-59.

WELCH, J.R., BRONDÍZIO, E.S., HETRICK, S.S. \& COIMBRA JR, C.E.A. 2013a. Indigenous burning as conservation practice: neotropical savanna recovery amid agribusiness deforestation in Central Brazil. PLOS ONE 8:e81226.

WELCH, J.R., COIMBRA JR., C.E.A. 2019. Indigenous fire ecologies, restoration, and territorial sovereignty in the Brazilian Cerrado: the case of two Xavante reserves. Land Use Policy 104:104055.

WELCH, J.R., LECOMPTE-MASTENBROOK, J., BUTZ, R.J., STEWARD, A.M. \& RUSSELL-SMITH, J. 2018. Anthropogenic fire history, ecology, and management in fire-prone landscapes: an intercontinental review. In Fire Otherwise: Ethnobiology of Burning for a Changing World (C.T. Fowler \& J.R. Welch, eds.). The University of Utah Press, Salt Lake City, p.22-62.

WELCH, J.R., SANTOS, R.V., FLOWERS, N.M. \& COIMBRA Jr, C.E.A. 2013b. Na primeira margem do rio: território e ecologia do povo Xavante de Wedezé. Museu do Índio/FUNAI, Rio de Janeiro.

Received: 05/04/2021

Accepted: 26/11/2021

Published online: 12/01/2022 